\title{
SUBJEK HUKUM DAN OBJEK HUKUM: SEBUAH TINJAUAN HUKUM ISLAM, PIDANA, DAN PERDATA
}

\author{
Doli Witro ${ }^{1 *}$, Mhd. Rasidin², Muhamad Izazi Nurjaman ${ }^{1}$ \\ ${ }^{1}$ UIN Sunan Gunung Djati Bandung \\ 2Institut Agama Islam Negeri Kerinci \\ *Corresponding author: doliwitro01@gmail.com
}

\begin{abstract}
When discussing syara' law, it is always bound by four things, namely alHakim, law, mahkumalaih, and mahkumfih. In various legal studies, there are various views in determining that a person can be subject to law, or in other words, capable of law. In essence, everyone is a good bearer, that is, someone who has rights and obligations. Rights bearers are also known as legal subjects. The term legal subject in the discipline of Islamic law is mentioned as mahkumalaih. If there is a legal subject, it will always go hand in hand with a legal object. In the discipline of Islamic law, the object of the law is also called mahkumfih. This article aims to discuss mahkumalaih and mahkumfih in the discipline of Islamic law. The study uses a qualitative approach that is a literature review. The materials for this article were obtained from books, journals, and internet websites related, namely mahkumalaih, and mahkumfih. The data analysis techniques used were data presentation, data reduction, and conclusion drawing. The findings showed that mahkumfih is a legal object or is interpreted as an act of mukallaf based on Allah and the Prophet's command. In the discussion of legal objects, it cannot be separated from the legal subject. In ushulfigh the subject of law is called mahkumalaih.
\end{abstract}

Keywords: Mahkum Alaih, Mahkum Fih, Ushul Fikih

\begin{abstract}
Abstrak
Jika membicarakan hukum syara', setidaknya selalu terikat dengan empat hal yaitu yaitu al-Hakim, hukum, mahkum alaih dan mahkum fih. Dalam berbagai tinjauan ilmu hukum, terdapat pandangan yang bermacam-macam dalam menetapkan seseorang itu dapat dikenakan hukum, atau dalam bahasa lain, cakap hukum. Pada hakikatnya setiap orang merupakan pembawa hak, yakni seseorang yang mempunyai hak dan kewajiban. Pembawa hak dikenal juga dengan istilah subjek hukum. Istilah subjek hukum dalam disiplin hukum
\end{abstract}


Islam disebutkan dengan mahkum alaih. Kalau terdapat subjek hukum, maka akan selalu bergandengan dengan obyek hukum. Dalam disiplin hukum Islam, obyek hukum disebut juga dengan mahkum fih. Artikel bertujuan memberi pemahaman tentang mahkum alaih dan mahkum fih dalam disiplin hukum Islam. Artikel ini menggunakan pendekatan kualitatif yang bersifat kajian pustaka. Bahan-bahan artikel ini diperoleh dari buku, jurnal, dan website internet yang berkaitan dengan teman artikel ini yaitu mahkum alaih dan mahkum fih. Teknis analisis data yang digunakan yaitu penyajian data, reduksi data, dan penarikan kesimpulan. Hasil penelitian menunjukan mahkum fih adalah objek hukum atau diartikan sebagai perbuatan mukallaf yang berkaitan dengan perintah Allah dan Rasul. Dalam pembahasan objek hukum tidak terlepas dari subjek hukum. Dalam ilmu ushul fikih subjek hukum disebut dengan mahkum alaih.

Keywords: Mahkum Alaih, Mahkum Fih, Ushul Fikih

\section{A. PENDAHULUAN}

Jika membicarakan hukum syara', setidaknya selalu terikat dengan empat hal yaitu yaitu al-Hakim, hukum, mahkum alaih dan mahkum fih. AlJurjani mengartikan hukum syara' sebagai penjelasan hukum yang berasal dari Allah tentang perbuatan yang dilakukan mukalaf (manusia yang dibebani hukum). Mayoritas ulama mengatakan hukum syara' ialah kalam Allah yang berkaitan dengan orang yang berakal sehat dan orang dewasa yang bersifat perintah, atau bersifat pilihan, atau menentukan sesuatu syarat, sebab, dan penghalang. ${ }^{1}$ Hukum syara' berasal atau bersumber dari al-Hakim. Dalam kajian ushul fikih, al-hakim dikenal juga dengan istilah syari'.2 Dalam pengertian lain, al-Hakim dikenal dengan pembuat hukum atau pembentuk hukum syara'. Pembuat hukum syara' tidak lain dan tidak bukan adalah Allah s.w.t. ${ }^{3}$

1 Shindu Irwansyah, "Perbuatan Dan Pertanggungjawaban Hukum Dalam Bingkai Ushul Fikih," Tahkim: Jurnal Peradaban Dan Hukum Islam 1, no. 1 (2018): 89, https://doi.org/10.29313/tahkim.v1i1.3223.

2 Rachmat Syafe'i, Ilmu Ushul Fiqih (Bandung: Pustaka Setia, 2010), 345.

${ }^{3}$ Imam Yazid, Ilmu Fikih Dan Ilmu Usul Fikih (Medan: Fakultas Ilmu Sosial Universitas Islam Negeri Sumatera Utara, 2016), 9. 
Allah s.w.t. menurunkan hukum atau menetapkan peraturan-peraturan dalam hidup manusia bukan untuk memberatkan manusia dalam menjalani hidupnya. Tetapi memberikan pedoman agar manusia tidak tersesat ke jalan yang salah. Fathi Ridlwan sebagaimana yang dikutip oleh H. M. A. Tihami menyatakan dikenakannya (ditaklifkan) hukum syara' kepada manusia karena nilai kemanusiaan yang ada pada manusia itu sendiri. ${ }^{4}$ Artinya, manusia sebagai makhluk ciptaan Allah yang sempurna harus menunjukkan tingkah laku yang sempurna pula. Salah satu bentuk perilaku yang sempurna tersebut adalah dengan bertaqwa kepada Allah s.w.t. Bentuk ketaqwaan manusia kepada Allah tercermin dalam ucapan dan dibuktikan dengan perbuatan dengan menjauhi semua larangan-Nya dan mengerjakan semua perintah-Nya. Kewajiban manusia dalam bertaqwa kepada Allah, dimulai pada saat seseorang ditetapkan sebagai mukallaf.

Dalam berbagai tinjauan ilmu hukum, terdapat pandangan yang bermacam-macam dalam menetapkan seseorang itu dapat dikenakan hukum, atau dalam bahasa lain, cakap hukum. Cakap hukum (legal capacity) dalam hukum pidana dan hukum perdata dikenal dengan istilah dewasa. Meskipun terdapat istilah yang sama yaitu cakap hukum yang digunakan dalam beberapa disiplin hukum. Namun tidak dalam hukum Islam, yang menggunakan istilah mukallaf. Pada hakikatnya setiap orang merupakan pembawa hak, yakni seseorang yang mempunyai hak dan kewajiban. Pembawa hak dikenal juga dengan istilah subjek hukum. ${ }^{5}$ Istilah subjek hukum dalam disiplin hukum Islam disebutkan dengan mahkum alaih. Kalau terdapat subjek hukum, maka akan selalu bergandengan dengan obyek

${ }^{4}$ H. M. A. Tihami, “Antropologi Fiqh (Gambaran Tentang Isyarat Dan Pendekatan)," Al-Qalam 17, no. 85 (2000): https://doi.org/https://www.researchgate.net/deref/http\%3A\%2F\%2Fdx.doi.org\%2F10.326 78\%2Falqalam.v17i85.1474.

5 Nahrowi Nahrowi, "Penentuan Dewasa Menurut Hukum Islam Dan Berbagai Disiplin Hukum," Kordinat 15, no. 2 (2016): 253-354, https://doi.org/10.15408/kordinat.v15i2.6333. 
hukum. Dalam disiplin hukum Islam, obyek hukum disebut juga dengan mahkum fih.

Penelitian tentang mahkum alaih dan mahkum fih telah dilakukan. Nahrowi, dalam Penentuan Dewasa Menurut Hukum Islam dan Berbagai Disiplin Hukum $^{6}$ Tulisan ini menjelaskan dewasa yang dilihat dalam berbagai aspek ilmu hukum. Satu di antara ketentuan cakap hukum adalah dewasa. Seseorang yang melakukan suatu perbuatan, untuk menentukan sah atau tidaknya perbuatan tersebut, maka harus ditinjau dari kecakapan hukum. Dalam tulisan ini, Nahrowi menjelaskan setidaknya ada beberapa sudut pandangan hukum yang harus dilihat untuk menentukan seseorang cakap hukum di Indonesia, yaitu sudut pandangan hukum perdata, sudut pandang hukum pidana, sudut pandangan hukum ketatanegaraan sudut pandangan hukum Islam, dan sudut pandangan hukum adat. Lebih lanjut, Nahrowi menyimpulkan dalam pandangan hukum perdata, hukum pidana dan hukum ketatanegaraan memandang berbeda kecakapan hukum seseorang atau dewasa dengan ditetapkan usia yang berbeda-beda. Selain itu, juga mengalami perbedaan dalam hal sanksi yang diberikan terhadap seseorang melakukan suatu perbuatan yang dapat menimbulkan akibat hukum tertentu. Batasan yang digunakan dalam sudut pandang hukum-hukum tersebut adalah kuantitas umur. Begitu juga dengan sudut pandang hukum lain yaitu hukum Islam dan hukum adat. Hukum Islam dan hukum adat memandang kecakapan (dewasa) seseorang lebih kepada ciri-ciri fisik yang ada pada diri seseorang tersebut. Namun bukan pada sisi kuantitas umur. Meskipun ada sebagian dari masyarakat atau daerah yang menggunakan umur sebagai batasan untuk menentukan seseorang telah dewasa. Sebagaimana yang terjadi dalam adat masyarakat Batak. Hukum."

${ }^{6}$ Nahrowi, "Penentuan Dewasa Menurut Hukum Islam Dan Berbagai Disiplin 
Shindu Irwansyah, dalam Perbuatan Dan Pertanggungjawaban Hukum Dalam Bingkai Ushul Fikih.' Tulisan ini menjelaskan kembali siapa mukhatab yang dimaksudkan oleh Allah s.w.t. (syari'), apa saja yang menjadi pertanggungjawaban, dan apa pengetahuan yang dimilikinya. Lebih lanjut Irwansyah menjelaskan ada sebagian kalangan yang mengatakan ushul fikih telah tertinggal oleh metodologi hukum modern yang mengalami perkembangan cepat di dalam memberikan solusi dan menjawab tantangan hukum modern saat ini. Pembahasan mengenai mahkum alaih menjadi urgen terkait dengan kondisi tertentu, pribadi tertentu, dan masyarakat tertentu yang dibebani hukum taklif. Terakhir Irwansyah mengatakan rumusan normatif saat ini masih menyisakan ruang yang butuh sentuhan oleh akademisi yang berkompeten dan concern pada bidangnya yang memiliki pikiran yang cerdas dan berani.

Zaenudin Mansyur, Pandangan Tuan Guru Tentang Anak Sebagai Mahkūm 'alaih Dalam Akad Muamalah Kontemporer Di Kota Mataram. ${ }^{8}$ Artikel ini mengemukakan terdapat perbedaan pandangan para ulama dalam menentukan status anak sebagai mahkum alaih sehingga membuka pintu ijtihad Tuan Guru dalam menjelaskan pendapat yang relevan untuk mengatasi keresahan masyarakat. Tulisan ini merupakan tulisan dari penelitian lapangan yang dilakukan di Kota Mataram, yang berangkat dari viralnya bisnis menggunakan alat teknologi dalam bertransaksi muamalah kontemporer. Kebanyakan dari Tuan Guru menyelesaikan masalah hukum berdasar pada pernyataan ulama mazhab dahulu. Mayoritas dari mereka sangat tekstual dalam menjawab permasalahan agama, bahkan ada sebagian dari mereka yang bertaklid terhadap ulama mazhab (Hanafi, Maliki, Syafi'i dan

7 Irwansyah, "Perbuatan Dan Pertanggungjawaban Hukum Dalam Bingkai Ushul Fikih."

8 Zaenudin Mansyur, "Pandangan Tuan Guru Tentang Anak Sebagai Mahkūm 'alaih Dalam Akad Muamalah Kontemporer Di Kota Mataram," Mu'amalat: Jurnal Kajian Hukum Ekonomi 7, no. $\quad 1 \quad$ (2015): https://journal.uinmataram.ac.id/index.php/muamalat/article/view/1166. 
Hanbali). Lebih lanjut, Mansyur menyimpulkan bahwa kedudukan anak sebagai mahkum alaih dalam hukum Islam dalam transaksi muamalah kontemporer, tidak sah selama ia belum mukallaf. Seseorang yang dapat dikatakan mukalaf, jika ia telah baligh yang bertandakan telah ihtilam bagi lakilaki dan perempuan telah mengalami haid. Tuan Guru mengemukakan setidaknya ada tiga pendapat mengenai anak yang melakukan transaksi muamalah kontemporer yaitu pada bisnis yang menggunakan teknologi. Pertama, seorang anak tidak bisa dikatakan sebagai mahkum alaih walaupun memiliki kecerdasan dalam melakukan transaksi. Kedua, seorang anak dapat menjadi mahkum alaih dalam wilayah transaksi yang bersifat ringan saja. Ketiga, seorang anak dapat menjadi mahkum alaih apabila telah mendapatkan izin dari orang tua atau walinya.

Artikel ini membahas mahkum alaih dan mahkum fih dalam ilmu ushul fikih. Hal ini penting untuk dibahas, karena mahkum alaih dan mahkum fih akan menentukan sah tidaknya atau bisa tidaknya seseorang dibebankan hukum. Terlebih dalam bidang muamalah (hukum ekonomi syari'ah), mahkum alaih dan mahkum fih akan menentukan sah atau tidaknya seseorang dalam melakukan akad atau transaksi jual beli. Artikel bertujuan memberi pemahaman tentang mahkum alaih dan mahkum fih dalam disiplin hukum Islam.

\section{B. METODOLOGI PENELITIAN}

Artikel ini menggunakan pendekatan kualitatif yang bersifat kajian pustaka. Bahan-bahan artikel ini diperoleh dari buku, jurnal, dan website internet yang berkaitan dengan teman artikel ini yaitu mahkum alaih dan mahkum fih. Data-data dikumpulkan dengan cara membaca, menelaah, dan memahami setiap bahan yang diperoleh. Data-data yang sudah disaring tersebut dianalisis dengan metode analisis data yang dikenal dengan Miles dan Huberman yaitu penyajian data, reduksi data, dan penarikan 
kesimpulan. ${ }^{9}$

\section{HASIL PENELITIAN DAN PEMBAHASAN}

\section{Mahkum Fih (Obyek Hukum)}

Mahkum fih dikenal juga dengan mahkum bih. Mahkum fih merupakan perbuatan mukallaf yang berkaitan dengan perintah syari' (Allah dan Rasul) yang ketika disifati dengan hukum taklifi menjadi wajib, sunah, mubah, makruh, dan haram. ${ }^{10}$ Kalau dalam konteks hukum wadh'i, perbuatan mukallaf bisa berbentuk jinayat dan muamalah. Kadang tidak berupa perbuatan mukalaf, misal ketika seseorang mendapatkan bulan ramadhan, maka menjadi sebab baginya untuk wajib berpuasa. ${ }^{11}$ Makkum fih yang berkaitan dengan perbuatan manusia sebagaimana yang terdapat dalam surat al-Baqarah ayat 277:

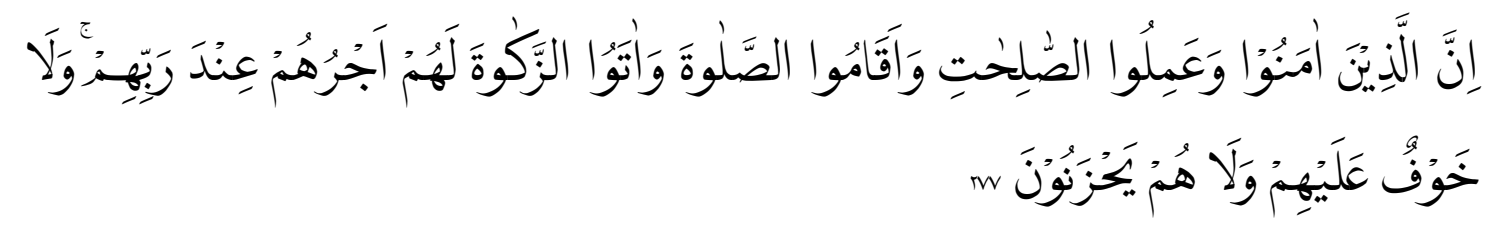

Artinya:

Sungguh, orang-orang yang beriman, mengerjakan kebajikan, melaksanakan salat dan menunaikan zakat, mereka mendapat pahala di sisi Tuhannya. Tidak ada rasa takut pada mereka dan mereka tidak bersedih hati. ${ }^{12}$

Ath-Thabari dalam Tafsir Ath-Thabari menjelaskan orang-orang yang beriman adalah mereka yang mempercayai Allah dan Rasul-Nya. Mereka percaya akan riba merupakan perbuatan yang haram dilakukan. Kemudian

${ }^{9}$ Matthew B. Miles and A. Michael Huberman, Qualitative Data Analysis (a Source Book of New Methods) (Beverly Hills: Sage Publications, 1984), 21-24.

${ }^{10}$ A. Khisni, EPISTEMOLOGI HUKUM ISLAM (Sumber Dan Dalil Hukum Islam, Metode Islimbath Dan Ijtihad Dalam Kajian Epistemologi Usul Fikih) (Semarang: Unissula Press, 2012), 15.

${ }_{11}$ Irwansyah, "Perbuatan Dan Pertanggungjawaban Hukum Dalam Bingkai Ushul Fikih," 95; Amir Syarifuddin, Ushul Figh, Jilid I (Jakarta: Logos Wacana Ilmu, 1999), 350.

12 Departemen Agama RI, Al-Quran Dan Terjemahnya (Bandung: Syaamil Qur'an, 2010), 47. 
mereka mengerjakan amal saleh, mendirikan shalat, dan membayar zakat atas perintah Allah s.w.t. dan mengerjakan sunah yang dianjurkan kepada mereka. ${ }^{13}$ Lebih lanjut, M. Quraish Shihab mengemukakan apabila dilihat ayat-ayat sebelum ayat menjelaskan mengenai balasan terhadap orang-orang yang kafur atas nikmat dan mengerjakan perbuatan dosa. Oleh karena ayat ini, menjelaskan balasan-balasan yang akan diberikan kepada orang yang mengerjakan amal-amal saleh. ${ }^{14}$ Berangkat dari ayat ini dipahami bahwa perbuatan mukallaf yang berkaitan dengan hukum yaitu kewajiban shalat dan kewajiban membayar zakat. ${ }^{15}$ Contoh lain seperti yang terdapat surat al-Isra' ayat 32:

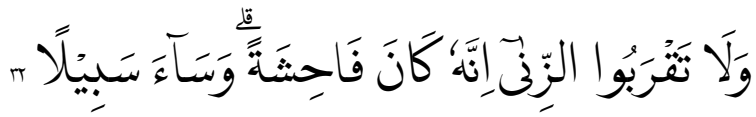

Artinya:

Dan janganlah kamu mendekati zina; (zina) itu sungguh suatu perbuatan keji, dan suatu jalan yang buruk. ${ }^{16}$

Ath-Thabari dalam Tafsir Ath-Thabari menjelaskan Allah telah memerintahkan manusia agar tidak mendekati zina, karena zina merupakan perbuatan yang keji. Zina merupakan jalan yang buruk, dan tidak boleh didekati karena termasuk jalan ahli maksiat. ${ }^{17}$ Para ahli tafsir mengemukakan ayat yang terdapat di dalamnya terdapat kata "jangan mendekati" bermaksud larangan mendekati sesuatu yang dapat merangsang nafsu/jiwa untuk mengerjakannya. Oleh karenanya, tidak diperbolehkan untuk mendekati sesuatu mempunyai makna larangan agar seseorang tidak terjerumus pada

13 Abu Ja'far Muhammad bin Jarir Ath-Thabari, Tafsir Ath-Thabari, Jilid 4 (Jakarta: Pustaka Azzam, 2007), 739.

${ }^{14}$ M. Quraish Shihab, Tafsir Al Mishbah: Pesan, Kesan Dan Keserasian Al-Qur'an Volume 1 (Jakarta: Lentera Hati, 2005), 596. Fikih," 95.

${ }^{15}$ Irwansyah, "Perbuatan Dan Pertanggungjawaban Hukum Dalam Bingkai Ushul

${ }^{16}$ Departemen Agama RI, Al-Quran Dan Terjemahnya, 285.

17 Abu Ja'far Muhammad bin Jarir Ath-Thabari, Tafsir Ath-Thabari, Jilid 16 (Jakarta: Pustaka Azzam, 2007), 656. 
perbuatan yang berpeluang mengantarkan kepada langkah mengerjakannya. ${ }^{18}$ Berangkat dari ayat ini dapat dipahami hukum yang terkait dengan perbuatan mukalaf yaitu larangan melakukan perbuatan zina. Ayat ini juga menegaskan, jangankan melakukan perbuatan zina, mendekatinya saja tidak dibolehkan. Karena sesungguhnya perbuatan zina itu termasuk perbuatan keji dan merupakan perbuatan yang dapat membawa manusia kepada jalan yang buruk.

\section{Syarat-Syarat Sah Taklif}

Pertama, mukallaf yang mampu memahami taklif. Baik taklif yang diketahui sendiri ataupun diketahui melalui perantara orang lain. Karena pada dasarnya tujuan daripada taklif agar segala hukum yang diberikan (dikenakan) pada mukallaf dapat dipatuhi dan ditaati. Artinya, orang yang tidak memahami perintah Allah secara otomatis tidak akan dapat mematuhinya. Secara sederhana, perintah dalam memahami hukum syara' merupakan pondasi dari taklif itu sendiri. ${ }^{19}$ Pekerjaan atau perbuatan yang dikenakan kepada mukalaf harus bersifat ma'lum (dapat diketahui) secara sempurna. Kalau perbuatan yang tidak diketahui maka tidak sah. Oleh karenanya, taklif-taklif yang disebutkan dalam Al-Quran masih bersifat sangat umum (global) seperti shalat dan zakat. Perintah yang bersifat global tersebut kemudian dijelaskan oleh Rasulullah s.a.w. ${ }^{20}$

Kedua, berakal. Seseorang mukallaf yang dibebankan taklif harus memiliki akal yang baik dan tidak seperti anak kecil, orang gila, dan orang yang sedang tidur. Sebagaimana yang disabdakan Nabi s.a.w.:

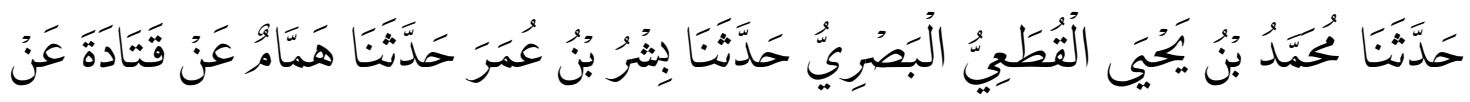

${ }_{18}$ M. Quraish Shihab, Tafsir Al Mishbah: Pesan, Kesan Dan Keserasian Al-Qur'an Volume 7 (Jakarta: Lentera Hati, 2005), 458-59. Fikih," 96.

19 Irwansyah, "Perbuatan Dan Pertanggungjawaban Hukum Dalam Bingkai Ushul ${ }^{20}$ Irwansyah, 95-96. 


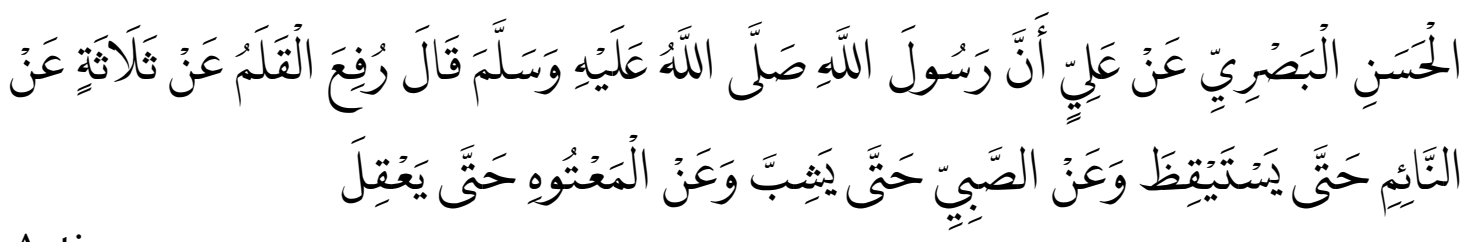

Artinya:

Muhammad bin Yahya Al Qutha'i Al Bashri menceritakan kepada kami, Bisyr bin Umar menceritakan kepada kami, Hammam menceritakan kepada kami dari Qatadah, dari Hasan Al Bashri, dari Ali, bahwa Rasulullah SAW bersabda, "Qalam (pena) diangkat dari tiga orang (maksudnya, mereka tidak dibebani hukum): orang yang tidur hingga dia terjaga, anak kecil hingga ia dewasa (baligh) dan orang gila hingga ia sadar" (H. R. Tirmidzi).

\section{Mahkum Alaih (Subjek Hukum)}

Menurut Alauiddin Koto, mahkum alaih merupakan perbuatan mukallaf berhubungan dengan perintah Allah s.w.t. atau hukum Islam. Bisa dikatakan mahkum alaih merupakan mukallaf yang menjadi objek berlakunya hukum syara'. Alasan mengapa dinamakan sebagai mukallaf dikarenakan dialah seorang yang dikenai beban hukum. Jadi secara sederhana mahkum alaih adalah orang (subjek) yang melakukan perbuatan hukum tersebut. ${ }^{21}$

Mahkum alaih merupakan orang-orang yang dibebani hukum (orangorang mukallaf itu sendiri). Menurut pandangan Abdul Wahhab Khallaf, ia menjelaskan bahwa mahkum alaih adalah pembebanan hukum kepada orangorang mukallaf atas pebuatan yang dilakukannya. ${ }^{22}$ Kemudian pandangan Chaerul Uman yang memandang dari aspek kebahasaan bahwa mahkum alaih orang-orang yang perbuatannya diatur atau dikenai khitab Allah s.w.t. Dalam istilah ushul fikih, mukallaf setingkali disebut sebagai subjek hukum. Maka dari itu, mukallaf diartikan orang yang dianggap mampu berbuat hukum, baik perbuatan yang diperbolehkan maupun perbuatan yang dilarang. Mukallaf telah diberikan kewajiban, larangan, ataupun anjuran. Artinya, jika seseorang

${ }^{21}$ Irwansyah, 98.

22 Abdul Wahhab Khalaf, Ilmu Ushul Al-Figh (Beirut: Dar al-Kutub al-'Ilmiyah, 1971), 105. 
tersebut melakukan ibadah, maka ia akan mendapatkan pahala atas perbuatan tersebut. Begitu juga sebaliknya jika ia berbuat salah, maka akan diberikan beban hukuman yang harus dilaksanakan. ${ }^{23}$

\section{Syarat-Syarat Mahkum Alaih}

Secara umum, ada dua persyaratan bagi mukallaf agar sah untuk ditaklifi. Pertama, orang tersebut mampu memahami dalil-dalil taklif itu sendiri, melalui dirinya atau bantuan orang lain. Karena secara otomatis jika orang tersebut tidak memahami dalil-dalil taklif, maka tidak akan mungkin orang tersebut mematuhi yang ditaklifkan kepadanya. Dalam memahami taklif, yang hanya mampu dalam menangkapnya adalah akal. Akal menjadi alat untuk memahami taklif. Itulah alasan Allah memberikan syaratnya adalah orang-orang yang baligh, dikarenakan akal akan menjadi alat utama untuk memahami taklif.

Seseorang yang masuk kriteria dalam persyaratan taklif, maka ia harus mampu mentaklifkan dalil pentaklifan. Artinya, ia mampu memahami Al-Quran dan Sunnah sebagai sumber hukum Islam untuk dipahami yang kemudian dijalani baik atas dirinya sendiri maupun melalui perantara orang lain. Karena pada dasarnya orang yang tidak mampu memahami dalil-dalil pentaklifan, maka sesungguhnya tidak akan mungkin mampu melaksanakan atau melakukan perbuatan sesuai dengan taklif yang ditunjukkan kepadanya. ${ }^{24}$

Perbuatan atau pekerjaan dapat ditinggal atau dikerjakan oleh seseorang mukalaf, karena pada hakikat tujuan dari taklif adalah untuk dipatuhi sehingga kalau perbuatan yang dibebani kepada masalah itu di luar kemampuan itu sendiri, maka tidak mungkin akan dapat terwujud. ${ }^{25}$ Setidaknya ada dua yang menjadi syarat dalam hal ini: 1) taklif merupakan

23 Nahrowi, "Penentuan Dewasa Menurut Hukum Islam Dan Berbagai Disiplin Hukum," 259.

${ }^{24}$ Nahrowi, 259-60.

${ }^{25}$ Muhammad Ma'shum Zein, Ilmu Ushul Fiqih (Jombang: Darul Hikmah, 2008), 164. 
perbuatan yang bisa dilakukan dan bukan merupakan perbuatan yang mustahil dilakukan. Seperti meminta manusia untuk terbang tanpa sayap, menyeberangi lautan tanpa kapal, merobohkan gunung, dan lain sebagainya; 2) taklif yang berkaitan dengan perbuatan yang masih berada di dalam kendali manusia. Mayoritas ulama setuju bahwa seseorang yang telah mukalaf tidak akan disiksa jika ia mengerjakan perbuatan yang sanggup ia kerjakan misalnya shalat. Mukalaf tidak akan berdosa jika melakukan perbuatan ibadah yang tidak sanggup ia kerjaka, seperti melaksanakan haji ketika di situasi dan kondisi belum sanggup dan mampu.

Kedua, adalah orang yang "ahli" (cakap) bagi sesuatu yang telah dibebani baginya (yang ditaklifkan kepadanya). Ahli diartikan sebagai kepantasan dan kesanggupan yang ada pada diri seseorang. Dengan adanya kesanggupan yang ada padanya tersebut ia mampu mengerjakan perbuatan yang dibebankan kepadanya. Misalnya, seseorang diberikan tanggungjawab untuk mengurusi tanah wakaf, berarti ia secara mendasar pantas untuk diberikan tanggung jawab. Atau dalam bahasa lain dikatakan, "fulan adalah ahli (layak) memelihara wakaf ", artinya ia adalah orang yang pantas dan layak dibebani hukum seperti tidak gila dan sudah baligh. ${ }^{26}$ Dengan adanya kelayakan tersebut padanya dapat mengurus dan memelihara tanah wakaf yang diamanahkan kepadanya.

\section{Subjek Hukum dan Objek Hukum Dalam Hukum Pidana}

Dalam kajian ilmu hukum yang menjadi subjek hukum adalah manusia dan badan hukum 27 , begitu juga dalam hukum perdata maupun hukum pidana sebagai spesialisasi turunan dari kajian ilmu hukum. Pembahasan kedua subjek hukum tersebut, terdapat penjabaran khusus sehingga Fikih," 99.

26 Irwansyah, "Perbuatan Dan Pertanggungjawaban Hukum Dalam Bingkai Ushul 27 Marwan Mas, Pengantar Ilmu Hukum (Bogor: Ghalia Indonesia, 2015), 23. 
memperjelas kedudukan manusia dan badan hukum sebagai subjek dari kedua hukum tersebut. Manusia dalam pandangan hukum merupakan subjek hukum dan juga sebagai pelaku pendukung antara hak dan kewajiban, sehingga manusia memiliki kedudukan yang setara dalam perjalanan lalu lintas hukum. Pada dasarnya, manusia sebagai subjek hukum telah memperoleh hak dan kewajiban di mulai sejak ia lahir ke dunia dan berakhir ketika ia meninggal dunia, walaupun hak dan kewajibannya itu dapat dialihkan kepada ahli warisnya. ${ }^{28}$ Namun dalam pasal 2 KUHPerdata, terdapat pengecualian terhadap bayi yang masih dalam kandungan ibunya dinyatakan sebagai subjek hukum, apabila terdapat sebuah kepentingan yang menghendaki hal itu, khususnya dalam hal penerimaan harta warisan. Sehingga bayi tersebut dianggap telah lahir. Adapun apabila dalam perjalanannya bayi tersebut lahir dalam keadaan meninggal dunia, maka gugur hak bayi tersebut sebagai subjek hukum (khusus dalam penerimaan harta warisan maupun hibah) dan ia dinyatakan sebagai sesuatu yang dianggap tidak pernah ada. ${ }^{29}$

Adapun yang perlu diperhatikan adalah ketentuan kedudukan manusia sebagai subjek hukum adalah manusia memiliki kewenangan untuk melakukan tindakan hukum, ketika kedudukan manusia sudah dianggap dewasa, sehat jasmani dan rohani serta tidak berada dalam pengampuan. Karena dalam sejarah manusia, terdapat manusia yang tidak memiliki hak dan kewajiban, serta bukan termasuk subjek hukum perdata maupun pidana melainkan hanya sebagai objek dari hukum perdata yang dapat diperjualbelikan yaitu budak belian (hamba sahaya). Artinya, budak belian tersebut dipersamakan dengan barang atau benda. ${ }^{30}$

Selain itu juga, terdapat beberapa golongan manusia yang dinyatakan

${ }^{28}$ Neng Yani Nurhayani, Hukum Perdata (Bandung: CV Pustaka Setia, 2015), 72.

${ }^{29}$ Mas, Pengantar Ilmu Hukum, 23.

${ }^{30}$ Subekti Subekti, Pokok-Pokok Hukum Perdata (Jakarta: Pembimbing, 1959), 13. 
oleh hukum sebagai manusia yang tidak cakap untuk melakukan tindakan hukum sendiri melainkan perbuatan hukumnya harus diwakili oleh wali pengampu (orang tua atau wali/kuratornya). ${ }^{31}$ Golongan manusia tersebut dapat dikategorikan ke dalam beberapa bagian, pertama anak yang masih di bawah umur atau belum dewasa (belum berusia 21 tahun) dan belum kawin/ menikah. Kedua, orang dewasa yang berada di bawah pengampuan yaitu orang gila, pemabuk, pemboros, dan seorang perempuan (istri) dalam pernikahan. Serta orang dewasa yang hak dan kewajibannya dicabut sementara oleh hakim pengadilan, akibat melakukan tindakan kejahatan seperti pencabutan hak memegang jabatan kekuasaan, hak memilih dan dipilih, hak memasuki suatu pekerjaan dan sebagainya.

Sedangkan manusia yang cakap hukum selain sudah dewasa dan juga sudah menikah atau belum dewasa tapi sudah menikah berbeda ketentuan antara satu peraturan perundang-undangan satu dengan yang lainnya, antara lain:

Dalam hukum pidana, Pasal 45 dan 46 KUHPidana menyatakan bahwa secara eksplisit, sejatinya seseorang dapat dikatakan sebagai subjek hukum dan dapat dieksekusi perbuatan hukumnya dalam hukum pidana ketika sudah memenuhi syarat berusia 16 tahun atau dalam istilah Islam disebut baligh. ${ }^{32}$ Namun, seorang hakim dapat memutuskan perkara terkait kasus anak yang melakukan delik atau tindakan pidana di bawah usia 16 tahun yaitu, melakukan pembinaan dengan mengembalikannya kepada kedua orang tua atau ditempatkan di perumahan pemeliharaan anak negara dan menjatuhkan pidana dengan syarat mengurangi sepertiga dari ancaman pidana serta dimasukkan ke dalam penjara khusus anak. ${ }^{33}$

${ }^{31}$ Mas, Pengantar Ilmu Hukum, 24.

32 Nurkholis Nurkholis, "Penetapan Usia Dewasa Cakap Hukum Berdasarkan Undang-Undang Dan Hukum Islam," YUDISIA: Jurnal Pemikiran Hukum Dan Hukum Islam 8, no. 1 (April 8, 2018): 76, https://doi.org/10.21043/yudisia.v8i1.3223.

33 Mas, Pengantar Ilmu Hukum, 24. 
Dalam hukum perdata: ${ }^{34}$ pertama, menurut Pasal 29 KUHPerdata yang dikatakan dewasa adalah mereka yang sudah berusia 18 tahun bagi laki-laki dan 15 tahun bagi perempuan serta dalam Pasal 330 KUHPerdata yang berhak melakukan perbuatan hukum terhadap harta benda adalah mereka yang sudah berumur 21 tahun, sudah menikah atau pernah menikah. Kedua, pasal 7 (1) UU Nomor 1 Tahun 1974 tentang perkawinan adalah mereka yang berhak melangsungkan perkawinan adalah laki-laki berusia 19 tahun dan perempuan 16 tahun. Adapun bagi mereka yang berada di bawah usia 21 tahun, apabila mau melangsungkan pernikahan harus memiliki izin dari orang tua atau walinya. Ketiga, pasal 1 (34) UU Nomor 7 Tahun 2017 tentang pemilu adalah mereka yang berhak memilih adalah mereka yang sudah berusia 17 tahun (laki-laki dan perempuan) ditandai dengan sudah mempunyai Kartu Tanda Penduduk (KTP). Keempat, pasal 6 (3) UU Nomor 2006 Tentang Kewarganegaraan adalah mereka yang sudah dikatakan dewasa adalah mereka yang sudah berusia 18 baik laki maupun perempuan serta sudah menikah.

Selanjutnya, selain manusia yang menjadi subjek hukum pidana maupun perdata. Badan hukum menjadi salah satu subjek hukum di antara keduanya. Walaupun terdapat perbedaan pendapat di antara para pakar hukum, namun badan hukum diakui sebagai subjek hukum perdata maupun pidana dengan syarat dan ketentuan yang berlaku. Syarat dan ketentuan tersebut adalah terdapatnya teori ilmu hukum yang menjadi syarat suatu badan hukum dapat digolongkan sebagai subjek hukum, antara lain: pertama, badan hukum dianggap tidak ada dan hanya dibuat oleh negara serta hanya manusia yang dapat menghidupkan bayangannya untuk melakukan tindakan hukum. Sehingga badan hukum dapat melakukan perbuatan hukum bahkan perbuatan melawan hukum melalui mekanisme pelaksanaan kewenangan

34 Yati Nurhayati, Pengantar Ilmu Hukum (Bandung: Nusa Media, 2020), 29. 
suatu badan hukum untuk dilakukan oleh para pengurusnya sesuai bagian tugas dan wewenangnya. ${ }^{35}$ Artinya, apabila suatu badan hukum melakukan perbuatan melanggar hukum maka kedudukan badan hukum tidak bisa dituntut melainkan orang-orang yang mengelolanya yang dapat dituntut oleh hukum. Dengan demikian, badan hukum seperti halnya manusia dapat melakukan perbuatan hukum. Hal itu sesuai dengan teori fictie yaitu teori yang mempersamakan kedudukan badan hukum dengan manusia sebagai subjek hukum serta hukum memberikan hak dan kewajiban atasnya.

Kedua, teori kekayaan bertujuan yaitu teori yang menyatakan bahwa asset suatu badan hukum bukan merupakan asset milik pribadi sehingga harus adanya pemisahan asset antara milik badan hukum dengan asset para pengurusnya. Karena asset badan hukum terikat oleh sebuah tujuan bukan ditentukan oleh suatu subjek hukum. ${ }^{36}$ Namun, secara tidak langsung teori ini diperkuat dengan teori pemilikan bersama dan teori organ yaitu teori yang menyatakan bahwa suatu badan hukum hakikatnya adalah abstrak hanya berbentuk sebuah konstruksi yuridis namun berkat para penggeraknya badan hukum dinyatakan ada dalam pergaulan hukum. Maka hak dan kewajiban badan hukum merupakan hak dan kewajiban anggotanya sehingga berkaitan dengan asset badan hukum tidak dapat dibagi-bagi dari anggotanya secara bersama-sama melainkan sesuai dengan kehendak dan tujuan dari para anggotanya tersebut.

Selain diperkuat oleh teori organ, teori kekayaan bertujuan juga diperkuat oleh teori duguit yaitu teori yang menyatakan bahwa manusia adalah satu-satunya subjek hukum, adapun badan hukum bisa dikatakan sebagai subjek hukum hanya digerakkan oleh fungsi sosial manusia sebagai bagian dari anggotanya. ${ }^{37}$ Selain memenuhi syarat secara teori ilmu hukum,

35 Ishaq Ishaq, Dasar-Dasar Ilmu Hukum (Jakarta: Sinar Grafika, 2018), 62.

36 Yulia Yulia, Hukum Perdata (Lhokseumawe: CV Biena Edukasi, 2015), 7-8.

37 Nurhayani, Hukum Perdata, 75. 
suatu badan hukum juga harus memenuhi ketentuan syarat berdasarkan hukum yang berlaku, antara lain: ${ }^{38}$ didirikan melalui Akta Notaris, didaftarkan di Kepaniteraan Pengadilan Negeri di mana badan hukum berdiri, AD dan ART nya di sahkan oleh Kemenkumham serta diberitakan dalam Berita Negara.

Adapun yang menjadi catatan penting bahwa badan hukum bisa menjadi subjek hukum perdata adalah berlaku pada masalah harta kekayaan saja. Sedangkan dalam hukum pidana, badan hukum menjadi subjek hukumnya adalah ketika dalam melakukan perbuatan hukum perdata tersebut badan hukum melakukan tindakan perbuatan melawan hukum yang terdapat delik-delik yang berkaitan dengan hukum pidana. Artinya secara tidak langsung, badan hukum melakukan perbuatan hukum perdata, namun bisa dianggap melakukan perbuatan hukum pidana ketika dalam melakukan perbuatan hukum perdata terdapat delik-delik pidana yang dilakukan oleh oknum pengurusnya.

Sehingga dalam hukum pidana maupun hukum perdata subjek hukum disebut dengan pelaku hukum atau eksekutor hukum yaitu manusia itu sendiri ${ }^{39}$, atau manusia yang menjadi pelaku hukum atas nama suatu badan hukum. Dengan mengetahui subjek hukum pidana dan perdata yaitu manusia yang sudah dapat dikatakan sebagai seorang yang dewasa dan bukan anak kecil serta manusia yang melakukan perbuatan atas nama badan hukum patut dikenakan sebuah sanksi dalam hukum pidana atau perdata ketika keduanya terindikasi melakukan delik pidana atau perdata. Subjek hukum dalam mengeksekusi regulasi pemerintah yang berbentuk normatif harus mematuhi 2019), 41.

${ }^{38}$ Herlina Manulang, Pengatar Ilmu Hukum Indonesia (Medan: Bina Media Perintis,

39 Agustinus Danan Suka Dharma, "Keberagaman Pengaturan Batas Usia Dewasa Seseorang Untuk Melakukan Perbuatan Hukum Dalam Peraturan Perundang-Undangan Di

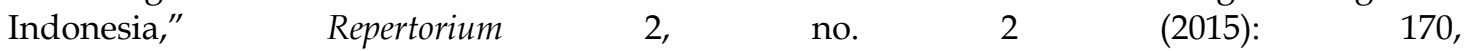
https://www.academia.edu/40990513/KEBERAGAMAN_PENGATURAN_BATAS_USIA_D EWASA_SESEORANG. 
regulasi norma yang sudah ditetapkan oleh pemerintah. ${ }^{40}$

Sehingga apabila seseorang yang sudah dewasa melakukan perbuatan delik pidana dan perdata dapat dikenakan konsekuensi hukum. ${ }^{41}$ Hal ini tidak lain untuk menjamin bahwa perbuatan yang dilakukan oleh seseorang atau subjek hukum agar dapat dipertanggungjawabkan secara hukum. ${ }^{42}$ Namun, sanksi yang diberikan terdapat perbedaan sesuai dengan delik yang dilakukan apakah dalam ranah hukum pidana atau dalam ranah hukum perdata. Dalam hukum pidana sanksi yang diberikan biasanya mengandung inti suatu ancaman pidana. ${ }^{43}$ Hal itu sesuai dengan Pasal 10 KUHPidana yang dapat berupa pidana pokok (pidana mati, pidana penjara, pidana kurungan, pidana denda dan pidana tutupan) dan pidana tambahan (pencabutan hakhak tertentu, perampasan barang tertentu dan pengumuman putusan hakim). Sedangkan sanksi bagi pelanggar hukum perdata dapat berupa kewajiban memenuhi prestasi dan hilangnya suatu keadaan hukum, serta dapat terciptanya suatu keadaan hukum baru yang mengikutinya.

Maka berdasarkan pemaparan tersebut, antara subjek hukum pidana dan hukum perdata memiliki kesamaan yaitu berupa manusia dan badan hukum sedangkan pembahasan terkait objek hukum dalam hukum pidana atau hukum perdata memiliki perbedaan. Di mana dalam hukum pidana yang menjadi objek hukum adalah dapat dilihat pada perbuatan manusia yang melanggar hukum pidana ataupun perundang-undangan terindikasi delik pidana serta pidana yang dapat dijatuhkan kepada pelanggar pidana. ${ }^{44}$ Perbuatan melanggar hukum tersebut bisa dilakukan oleh manusia itu sendiri

40 Nahrowi Nahrowi, "Penentuan Dewasa Menurut Hukum Islam Dan Berbagai Disiplin Hukum," 254.

${ }^{41}$ Nurwahidah Nurwahidah, "Usia Anak Dan Remaja Dalam Perbuatan Perdata Dan Pidana Menurut Hukum Islam Dan Hukum Positif," Syariah: Jurnal Hukum Dan Pemikiran 17, no. 2 (February 1, 2018): 204, https://doi.org/10.18592/sy.v17i2.1326.

${ }^{42}$ M Ghufron, "Makna Kedewasaan Dalam Perkawinan," Al-Hukama' 6, no. 2 (2016): 324, https://doi.org/10.15642/alhukama.2016.6.2.319-336.

43 Sofyan Sastrawidjaja, Hukum Pidana (Bandung: CV Armico, 1990), 39.

${ }^{44}$ Pipin Syarifin, Pengantar Ilmu Hukum (Bandung: Pustaka Setia, 1999), 65. 
atau manusia yang melakukan delik pidana atas nama suatu badan hukum.

Sedangkan yang menjadi objek hukum perdata adalah sesuai dengan objek pembahasan ilmu hukum yaitu berupa barang atau benda. Adapun sesuai Pasal 503 KUHPerdata, benda sendiri dapat dibedakan menjadi dua, yaitu benda yang berwujud dan benda tidak berwujud. Sehingga dalam pembahasan subjek hukum dan objek hukum dalam hukum pidana atau hukum perdata, yang menjadi aktor utama di dalamnya yaitu manusia dan manusia yang melakukan perbuatan hukum atas nama badan hukum sebagai subjek hukum dan perbuatan melawan hukum serta sanksi pidana yang diberikan sebagai objek hukum pidana sedangkan benda/barang menjadi objek hukum perdata. Dengan demikian, subjek dan objek hukum baik dalam hukum pidana maupun hukum perdata menjadi satu kesatuan yang terintegrasi berupa unsur yang sangat penting dalam setiap pembahasan kedua hukum tersebut.

\section{D.KESIMPULAN}

Berdasarkan uraian di atas dapat dipahami bahwa mahkum fih adalah objek hukum atau diartikan sebagai perbuatan mukallaf yang berkaitan dengan perintah Allah dan Rasul yang disifati dengan hukum taklifi, hukum wadh'i dan menjadi sebab diwajibkan/ditinggal suatu perbuatan oleh mukallaf. Dalam pembahasan objek hukum tidak terlepas dari subjek hukum. Dalam ilmu ushul fikih subjek hukum disebut dengan mahkum alaih. Bisa dikatakan mahkum alaih merupakan mukallaf yang menjadi objek berlakunya hukum syara'. Alasan mengapa dinamakan sebagai mukallaf dikarenakan dialah seorang yang dikenai beban hukum. Jadi secara sederhana mahkum alaih adalah orang (subjek) yang melakukan perbuatan hukum tersebut. Sementara dalam pembahasan subjek hukum dan objek hukum dalam hukum pidana atau hukum perdata, yang menjadi aktor di dalamnya yaitu manusia sebagai subjek hukum dan manusia juga sebagai objek hukum. 


\section{DAFTAR PUSTAKA}

Ath-Thabari, Abu Ja'far Muhammad bin Jarir. Tafsir Ath-Thabari, Jilid 16. Jakarta: Pustaka Azzam, 2007.

- - - Tafsir Ath-Thabari, Jilid 4. Jakarta: Pustaka Azzam, 2007.

Departemen Agama RI. Al-Quran Dan Terjemahnya. Bandung: Syaamil Qur'an, 2010.

Dharma, Agustinus Danan Suka. "Keberagaman Pengaturan Batas Usia Dewasa Seseorang Untuk Melakukan Perbuatan Hukum Dalam Peraturan Perundang-Undangan Di Indonesia." Repertorium 2, no. 2 (2015): 168-76. https://www.academia.edu/40990513/KEBERAGAMAN_PENGATUR AN_BATAS_USIA_DEWASA_SESEORANG.

Ghufron, M. “Makna Kedewasaan Dalam Perkawinan.” Al-Hukama' 6, no. 2 (2016): 319-36. https:// doi.org/10.15642/alhukama.2016.6.2.319-336.

Irwansyah, Shindu. "Perbuatan Dan Pertanggungjawaban Hukum Dalam Bingkai Ushul Fikih." Tahkim: Jurnal Peradaban Dan Hukum Islam 1, no. 1 (2018): 88-101. https://doi.org/10.29313/tahkim.v1i1.3223.

Khalaf, Abdul Wahhab. Ilmu Ushul Al-Figh. Beirut: Dar al-Kutub al-'Ilmiyah, 1971.

Khisni, A. EPISTEMOLOGI HUKUM ISLAM (Sumber Dan Dalil Hukum Islam, Metode Islimbath Dan Ijtihad Dalam Kajian Epistemologi Usul Fikih). Semarang: Unissula Press, 2012.

Mansyur, Zaenudin. “Pandangan Tuan Guru Tentang Anak Sebagai Mahkūm 'alaih Dalam Akad Muamalah Kontemporer Di Kota Mataram." Mu'amalat: Jurnal Kajian Hukum Ekonomi 7, no. 1 (2015): 1-26. https://journal.uinmataram.ac.id/index.php/muamalat/article/view/1 166. 
Manulang, Herlina. Pengatar Ilmu Hukum Indonesia. Medan: Bina Media Perintis, 2019.

Mas, Marwan. Pengantar Ilmu Hukum. Bogor: Ghalia Indonesia, 2015.

Miles, Matthew B., and A. Michael Huberman. Qualitative Data Analysis (a Source Book of New Methods). Beverly Hills: Sage Publications, 1984.

Nahrowi, Nahrowi. "Penentuan Dewasa Menurut Hukum Islam Dan Berbagai

Disiplin Hukum." Kordinat 15, no. 2 (2016): 253-74. https:/ / doi.org/10.15408/kordinat.v15i2.6333.

Nurhayani, Neng Yani. Hukum Perdata. Bandung: CV Pustaka Setia, 2015.

Nurhayati, Yati. Pengantar Ilmu Hukum. Bandung: Nusa Media, 2020.

Nurkholis, Nurkholis. "Penetapan Usia Dewasa Cakap Hukum Berdasarkan Undang-Undang Dan Hukum Islam." YUDISIA: Jurnal Pemikiran Hukum Dan Hukum Islam 8, no. 1 (April 8, 2018): 75-91. https://doi.org/10.21043/yudisia.v8i1.3223.

Nurwahidah, Nurwahidah. "Usia Anak Dan Remaja Dalam Perbuatan Perdata Dan Pidana Menurut Hukum Islam Dan Hukum Positif." Syariah: Jurnal Hukum Dan Pemikiran 17, no. 2 (February 1, 2018): 203-19. https://doi.org/10.18592/sy.v17i2.1326.

Sastrawidjaja, Sofyan. Hukum Pidana. Bandung: CV Armico, 1990.

Shihab, M. Quraish. Tafsir Al Mishbah: Pesan, Kesan Dan Keserasian Al-Qur'an Volume 1. Jakarta: Lentera Hati, 2005.

- - - Tafsir Al Mishbah: Pesan, Kesan Dan Keserasian Al-Qur'an Volume 7. Jakarta: Lentera Hati, 2005.

Subekti, Subekti. Pokok-Pokok Hukum Perdata. Jakarta: Pembimbing, 1959.

Syafe'i, Rachmat. Ilmu Ushul Fiqih. Bandung: Pustaka Setia, 2010.

Syarifin, Pipin. Pengantar Ilmu Hukum. Bandung: Pustaka Setia, 1999.

Syarifuddin, Amir. Ushul Figh, Jilid I. Jakarta: Logos Wacana Ilmu, 1999.

Tihami, H. M. A. "Antropologi Fiqh (Gambaran Tentang Isyarat Dan Pendekatan)." Al-Qalam 17, no. 85 (2000): 120-49. 
Subjek Hukum dan Objek Hukum

https://doi.org/https://www.researchgate.net/deref/http $\% 3 \mathrm{~A} \% 2 \mathrm{~F} \% 2 \mathrm{~F}$ dx.doi.org\%2F10.32678\%2Falqalam.v17i85.1474.

Yazid, Imam. Ilmu Fikih Dan Ilmu Usul Fikih. Medan: Fakultas Ilmu Sosial Universitas Islam Negeri Sumatera Utara, 2016.

Yulia, Yulia. Hukum Perdata. Lhokseumawe: CV Biena Edukasi, 2015.

Zein, Muhammad Ma'shum. Ilmu Ushul Fiqih. Jombang: Darul Hikmah, 2008. 